\title{
ANALISIS SPASIAL INDEKS STABILITAS UDARA DI INDONESIA
}

\author{
Spatial Analysis of Air Stability Index in Indonesia
}

\author{
Eka Fibriantika $^{1{ }^{1} *}$, Dian Mayangwulan ${ }^{1)}$ \\ ${ }^{1)}$ Badan Meteorologi Klimatologi dan Geofisika. Jl. Angkasa I No.2 Kemayoran, Jakarta Pusat 10720 \\ Indonesia \\ *E-mail : eka.fibriantika@bmkg.go.id
}

\begin{abstract}
Intisari
Indeks stabilitas udara merupakan salah satu parameter yang dapat dihasilkan dari pengolahan data Radiosonde. Pemetaan kondisi indeks stabilitas udara di Indonesia belum dilakukan. Diduga terdapat hubungan antara indeks stabilitas udara dengan curah hujan. Data yang digunakan dalam kajian ini adalah data Radiosonde di 22 stasiun pengamatan dan data TRMM wilayah Indonesia tahun 2019. Kajian ini bertujuan menganalisis indeks stabilitas udara di Indonesia secara spasial dan melihat hubungan antara indeks stabilitas udara dan curah hujan. Berdasarkan kajian yang telah dilakukan, bulan Januari merupakan bulan dengan nilai KI, SI, LI, dan TT paling kuat diikuti dengan sebaran curah hujan bulanan yang tinggi di sebagian besar wilayah Indonesia terutama Pulau Jawa. Sedangkan bulan September merupakan bulan paling stabil dengan nilai KI, SI, LI, dan TT paling lemah diikuti dengan kondisi kering di Indonesia. Pergerakan pelemahan indeks stabilitas udara dimulai dari wilayah NTT, NTB, Bali hingga terus melebar ke arah utara dimulai pada bulan Juni, dan perlahan menguat pada bulan Oktober.
\end{abstract}

Kata kunci : KI, Showalter Index, Lifted Index, Total-totals Index, TRMM

\begin{abstract}
The air stability index is one of the parameters that can be generated from Radiosonde data processing. Mapping the condition of the air stability index in Indonesia has not been done. It is suspected that there is a relationship between the air stability index and rainfall. The data used in this study are Radiosonde data of 22 observation stations and TRMM data for Indonesia in 2019. This study analyzes Indonesia's air stability indices spatially and sees the relationship between air stability indices with rainfall. Based on studies that have been carried out, January is the month with the strongest $\mathrm{KI}, \mathrm{SI}, \mathrm{LI}$, and TT values followed by the distribution of high monthly rainfall in most parts of Indonesia, especially Java Island. While September was the most stable month with the weakest KI, SI, LI, and TT values followed by Indonesia's dry conditions. The weakening of air stability indices began in the NTT, NTB, Bali regions, continued to expand northward starting in June, and slowly strengthened in October.
\end{abstract}

Keywords : KI, Showalter Index, Lifted Index, Total-totals Index, TRMM

\section{PENDAHULUAN}

Data Radiosonde merupakan salah satu hasil observasi udara atas yang penting dalam bidang meteorologi. Parameter cuaca yang didapatkan dari pengamatan Radiosonde diantaranya suhu udara, suhu titik embun, arah dan kecepatan angin, serta kelembaban udara. Jumlah stasiun meteorologi di Indonesia yang melakukan pengamatan Radiosonde dengan frequensi 2 kali dalam sehari sebanyak 22 lokasi. Indeks stabilitas udara merupakan salah satu parameter yang dapat dihasilkan dari pengolahan data Radiosonde. Beberapa penelitian terkait penggunaan data Radiosonde dan indeks stabilitas udara telah dilakukan. Syaifullah (2011) menggunakan data Radiosonde untuk menentukan proses pembentukan dan pertumbuhan awan konvektif (2011), analisis kondisi udara atas wilayah Jakarta bulan JanuariFebruari 2013 (2013), dan analisis kondisi udara atas wilayah Indonesia dengan menggunakan data 11 stasiun pengamatan Radiosonde (2018). Ferdiansyah (2012) menggunakan data Radiosonde untuk melihat potensi parameter keluaran RAOB sebagai indikator kunci dalam analisis curah hujan. Prediksi kejadian badai guntur dan hujan lebat dengan menggunakan indeks stabilitas udara juga telah dilakukan di wilayah Stasiun Meteorologi Cengkareng (Budiarti et al., 2012), di wilayah Makassar (Nurrohman \& Tjasyono, 2016) dan pada musim hujan tahun 2016 (Zahroh et al., 2017). Fibriantika \& Alhaqq (2018)) menggunakan data Radiosonde untuk mengamati profil vertikal atmosfer selama aktifitas Siklon tropis Cempaka 
dan Dahlia. Perbandingan pengukuran Radiometer dan Radiosonde juga telah dilakukan oleh Athoillah et al. (2016) dengan studi kasus pada musim hujan di Dramaga, Bogor.

Pemetaan kondisi indeks stabilitas udara di Indonesia belum dilakukan. Indeks stabilitas udara berkaitan erat dengan potensi pembentukan awan. Diduga terdapat hubungan antara indeks stabilitas udara dengan curah hujan. Penggunaan data TRMM memiliki korelasi yang tinggi dengan data pengamatan curah hujan dan berpotensi digunakan untuk mengisi data-data pengamatan yang kosong (Dodo, 2007). Kajian ini bertujuan menganalisis indeks stabilitas udara di Indonesia secara spasial dan melihat hubungan antara indeks stabilitas udara dengan curah hujan.

\section{METODE}

Pada kajian ini digunakan data indeks stabilitas udara dan TRMM. Data indeks stabilitas udara hasil pengamatan Radiosonde tahun 2019 pukul 00.00 UTC pada 22 Stasiun yaitu Stasiun Meteorologi Kualanamu, Minangkabau, Ranai, Sultan Iskandar Muda, Cilacap, Depati Amir, Fatmawati, Soekarno Hatta, Supadio, El tari, Iskandar, Juanda, Syamsuddin Noor, Tarakan, Hasanuddin, Mutiara,Patimura, Sam Ratulangi, Saumlaki, Fran Kaisiepo, Mopah, dan Sorong. Data tersebut diunduh dari situs http://weather.uwyo.edu/upperair/sounding.html.

Data indeks stabilitas udara yang dianalisis adalah $K$ Index (KI), Showalter Index (SI), Lifted Index (LI), dan Total-total Index (TT). Data tersebut dirata-ratakan tiap bulan.

$K$ index diukur berdasarkan nilai suhu ada lapisan 850, 700, dan $500 \mathrm{mb}$ dengan formula sebagai berikut,

$\mathrm{K}=\mathrm{T}_{850}-\mathrm{T}_{500}+\mathrm{T}_{\mathrm{d} 850}-\left(\mathrm{T}_{700}-\mathrm{T}_{\mathrm{d} 700}\right)$.

Showalter Index didapatkan dengan mengangkat parsel udara dari lapisan $850 \mathrm{mb}$ secara adiabatic hingga mencapai lapisan 500 mb. Berikut persamaan Showalter Index,

$S I=T_{e n v}-T_{\text {Lift }}$.

Lifted Index (LI) ditemukan oleh Joe Galway dengan mengangkat udara pada lapisan boundary layer dekat permukaan hingga mencapai lapisan $500 \mathrm{mb}$, kemudian membandingkan suhu parsel udara yang terangkat dengan suhu lingkungannya. Lifted index dapat dihitung dengan menggunakan persamaan berikut,

$L I=T_{e n v}-T_{\text {Lift }}$.

Total-totals Index (TT) ditemukan oleh U.S Air Force. Total-totals index terdiri atas dua bagian yaitu Cross Totals Index (CT) dan Vertical Totals Index (VT) berdasarkan data suhu ( $T$ ) dan suhu titik embun ( $T d$ ) pada lapisan 850 dan 500 $\mathrm{mb}$. Total-totals Index dapat dihitung dengan menggunakan persamaan sebagai berikut,

$C T=T_{d 850}-T_{500}$

$V T=T_{850}-T_{500}$

$T T=C T+V T$

((Budiarti et al., 2012) dan (Syaifullah, 2011)).

Software Phyton digunakan untuk menggambarkan kontur rata-rata bulanan indeks stabilitas udara. Digunakan metode interpolasi linear untuk melakukan interpolasi data pada software Phyton. Kategori masing-masing indeks terdapat pada Tabel 1.

Tabel 1. Kategori labilitas pada masing-masing indeks.

\begin{tabular}{|l|c|c|c|}
\hline \multirow{2}{*}{$\begin{array}{c}\text { Indeks } \\
\text { Labilitas }\end{array}$} & \multicolumn{3}{c|}{ Potensi Konveksi } \\
\cline { 2 - 4 } & Lemah & Sedang & Kuat \\
\hline $\begin{array}{l}\text { Showalter } \\
\text { Index }\end{array}$ & $>4$ & $4-(-4)$ & $<(-4)$ \\
\hline Lifted Index & $>-2$ & $(-2)-(-6)$ & $<(-6)$ \\
\hline K index & $<29$ & $29-37$ & $>37$ \\
\hline $\begin{array}{l}\text { Total-totals } \\
\text { Index }\end{array}$ & $<42$ & $42-46$ & $>46$ \\
\hline
\end{tabular}

(Sumber : Budiarti et al. (2012), Ferdiansyah (2012), Nurrohman \& Tjasyono (2016), Syaifullah (2017))

Data Tropical Rainfall Measuring Mission (TRMM) digunakan pada kajian ini untuk mengetahui jumlah curah hujan di Indonesia pada tahun 2019. Data akumulasi curah hujan bulanan dalam bentuk TRMM_3 B42RT_daily dengan format .nc diundūh dari situs https://giovanni.gsfc.nasa.gov/giovanni/. Software NCL digunakan untuk menampilkan data TRMM. Data TRMM_3 B42RT_daily merupakan data Realtime TRMM Multi-satellite Precipitation Analysis yang memiliki resolusi spasial hingga $0.25^{\circ}$ dan resolusi temporal per 3 jam.

\section{HASIL DAN PEMBAHASAN}

Analisis spasial $K$ Index (KI) pada bulan Januari (Gambar 1. a) menunjukkan seluruh wilayah Indonesia memiliki nilai KI 29 hingga 37 yang menunjukkan potensi konveksi sedang. Nilai KI pada bulan Februari (Gambar 1. b) di Kalimantan Timur dan Sumatera bagian Utara menunjukkan potensi konveksi lemah dengan $\mathrm{KI}$ sebesar 25-29 sedangkan untuk wilayah Indonesia lainnya masih memiliki potensi konveksi sedang dengan $\mathrm{KI}$ berkisar antara 29 hingga 37 . Bulan Maret nilai KI 
mulai turun terutama pada wilayah Kalimantan bagian Utara mencapai 17 hingga 25 (konveksi lemah) sedangkan wilayah Indonesia lainnya masih memiliki potensi konveksi sedang (Gambar 1. c).

Nilai KI mengalami kenaikan pada bulan April (Gambar 1.d) yaitu pada wilayah Kalimantan bagian utara menjadi 25 hingga 29 yang menunjukkan potensi konveksi lemah. Wilayah dengan potensi konveksi lemah lainnya adalah Papua Bagian selatan, NTT, dan NTB mengalami penurunan nilai KI menjadi 25 hingga 29. Sedangkan wilayah lainnya masih berpotensi konveksi sedang dengan nilai KI berkisar antara 29 hingga 37. Pada bulan Mei wilayah Sumatera bagian Selatan, Jawa, Bali, NTT, NTB, dan sebagian kecil Papua memiliki potensi konveksi lemah dengan nilai KI kurang dari 29. Sedangkan wilayah lainnya memiliki potensi konveksi sedang dengan nilai lebih dari 29 (Gambar 1.e).

Penurunan nilai KI secara signifikan terjadi pada bulan Juni. Potensi konveksi lemah berada pada sebagian besar Indonesia bagian Selatan terutama pada wilayah NTT, NTB, Bali, Jawa Timur, dan Jawa Tengah memiliki nilai $\mathrm{KI}$ antara 0 hingga 17 (Gambang 1.f). Sedangkan wilayah dengan potensi konveksi sedang dengan nilai 29 hingga 37 berada di Sulawesi, Sumatera, dan Kalimantan.

Analisis spasial $K$ Index $(\mathrm{KI})$ pada bulan Juli (Gambar 1. g) memiliki nilai KI antara 29 hingga 33, yaitu daerah bagian utara Sumatera, Kalimantan Utara, Gorontalo, Sulawesi Utara, Maluku Utara, dan sebagian Papua Barat. Selain wilayah tersebut, kondisi atmosfer memiliki potensi konveksi lemah (nilai KI kurang dari 29). Kondisi paling stabil (nilai KI kurang dari 17) yaitu wilayah Pulau Jawa, Bali, Nusa Tenggara Barat, Nusa Tenggara Timur, sebagian Kalimantan Selatan, dan sebagian Papua (Merauke).

Pada bulan Agustus (Gambar 1.h) wilayah Indonesia dengan potensi konveksi sedang (nilai KI 29 hingga 33), yaitu daerah bagian utara Pulau Sumatera, Kalimantan Utara, dan sebagian Papua Barat. Selain wilayah tersebut, memiliki potensi konveksi lemah (nilai KI kurang dari 29). Kondisi atmosfer paling stabil (nilai KI kurang dari 17) pada bulan ini, yaitu di wilayah Pulau Jawa, Bali, Nusa Tenggara Barat, dan Nusa Tenggara Timur, sebagian Kalimantan Selatan, dan meluas ke wilayah Sulawesi Selatan, Sulawesi Tenggara.

Pada bulan September (Gambar 1.i), wilayah Indonesia dengan potensi konveksi sedang (nilai KI 29 hingga 33) hanya di wilayah bagian utara Pulau Sumatera (Aceh dan Sumatera Utara), selain wilayah tersebut, memiliki kondisi potensi konveksi lemah (nilai KI kurang dari 29). Kondisi atmosfer paling stabil (nilai KI kurang dari 17) pada bulan ini meluas, yaitu di wilayah sebagian Lampung, Pulau Jawa, Bali, Nusa Tenggara Barat, dan Nusa Tenggara Timur, sebagian Kalimantan Selatan, Sulawesi Selatan, Sulawesi Tenggara, Maluku, dan sebagian Papua (Merauke).

Pada bulan Oktober (Gambar 1.j), kondisi atmosfer di wilayah bagian utara Sumatera, Kalimantan Barat, Kalimantan Tengah, Kalimantan Utara, dan sebagian Sorong memiliki potensi konveksi sedang (nilai Kl: 29 hingga 37). Selain wilayah tersebut, memiliki potensi konveksi lemah (nilai KI: kurang dari 29). Kondisi atmosfer paling stabil (nilai Kl: kurang dari 17) pada bulan Oktober berkurang dari bulan September, yaitu di wilayah Jawa Timur, Bali, Nusa Tenggara Barat, dan Nusa Tenggara Timur, sebagian Sulawesi Selatan, dan sebagian Merauke.

Pada bulan November (Gambar 1.k), wilayah potensi konveksi sedang (nilai KI 29 hingga 37) hampir sama dengan bulan Oktober, kecuali wilayah Sorong, nilai KI di Sorong menurun (potensi konveksi lemah). Kondisi atmosfer paling stabil (nilai KI kurang dari 17) pada bulan November semakin berkurang dari bulan sebelumnya, yaitu di wilayah Nusa Tenggara Timur, dan sebagian Merauke.

Pada bulan Desember (Gambar 1. I) wilayah dengan kategori potensi konveksi sedang (nilai KI 29 hingga 37) meluas dari bulan November, yaitu di wilayah Pulau Sumatera, Pulau Kalimantan, Banten, sebagian Jawa Timur, Pulau Sulawesi, Maluku Utara, dan Papua bagian utara. Selain wilayah tersebut nilai $\mathrm{KI}$ dalam rentang 21 hingga 29 (dalam kategori potensi konveksi lemah), yaitu di sebagian Jawa Barat, Jawa Tengah, Bali, Nusa Tenggara Barat, Nusa Tenggara Timur, dan Papua bagian selatan.

Berdasarkan penelitian yang dilakukan oleh Chakraborty et al. (2018) menunjukkan nilai KI pada wilayah Gadanki India memiliki nilai paling besar saat monsoon, yaitu lebih dari 30. Menurut Moron et al. (2009) monsun onset di Indonesia terjadi pada bulan Agustus-Desember. Qian et al. (2010) melakukan kajian terhadap angin monsunal tenggara yang terjadi selama SeptemberNovember (SON) dan angin monsunal barat laut selama Desember-Februari (DJF) di Pulau Jawa. Berdasarkan Gambar 1 Nilai KI yang memiliki potensi konveksi paling tinggi terjadi pada bulan Januari (monsun Asia). Hal ini sesuai dengan kajian yang dilakukan Chakraborty et al. (2018) walaupun waktu terjadinya monsun di India dan Indonesia berbeda. Sedangkan nilai KI yang paling stabil terjadi pada bulan September hal ini dikarenakan pada bulan ini merupakan akhir dari monsun Australia.

Nilai Showalter index (SI) pada bulan Januari (Gambar 2.a) menunjukkan bahwa wilayah Indonesia berada pada kategori potensi konveksi sedang dengan nilai SI -1 hingga 2 . Nilai SI pada bulan Februari (Gambar 2.b) relatif sama dengan bulan Januari yaitu berada pada kategori potensi konveksi sedang. Kondisi labilitas udara pada bulan Maret (Gambar 2.c) menunjukkan sebagian besar Indonesia memiliki potensi konveksi sedang, namun Kalimantan bagian utara menunjukkan potensi konveksi lemah. Pada bulan April (Gambar 2.d) kondisi labilitas udara kembali menguat menjadi potensi konveksi sedang kecuali wilayah Papua, NTT, 


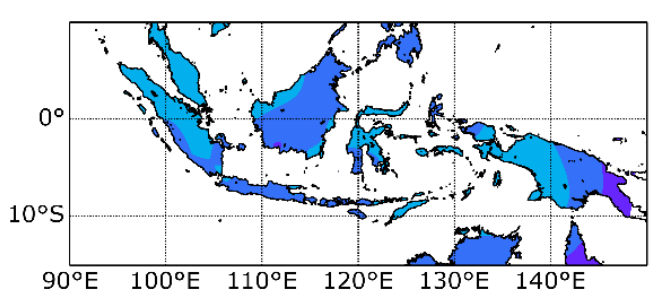

(a)

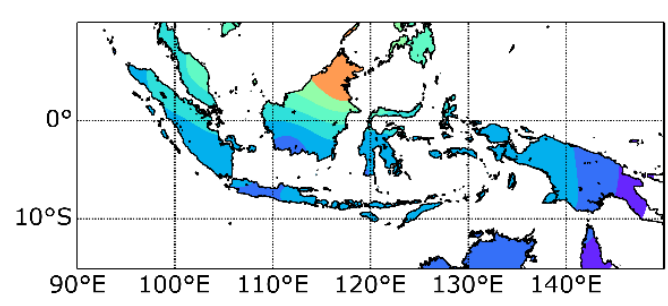

(c)

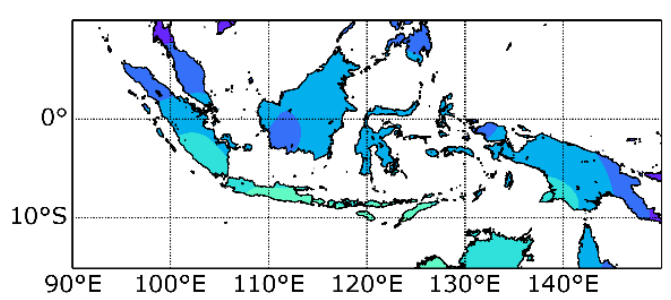

(e)

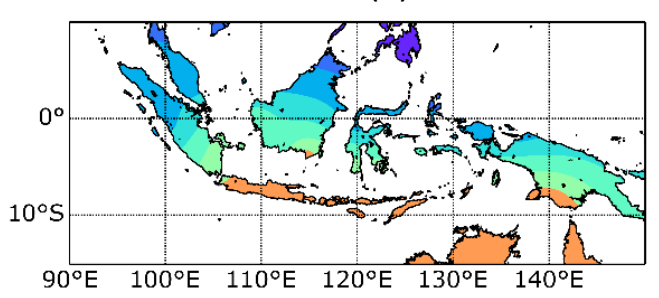

(g)

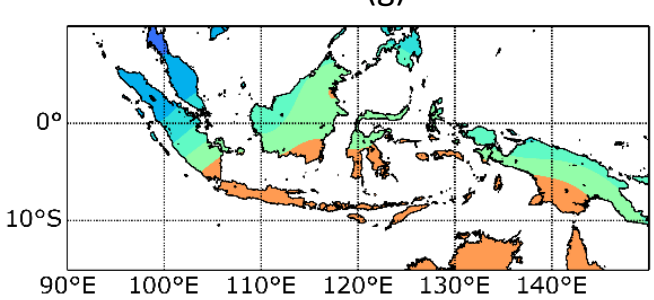

(i)

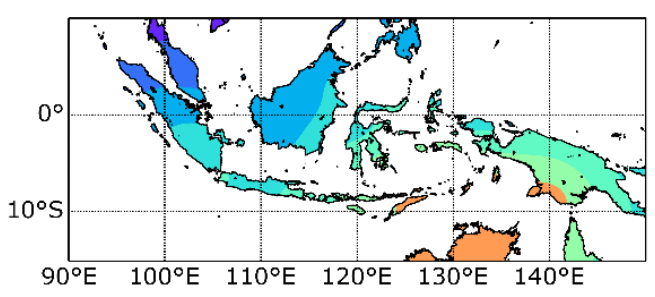

(k)

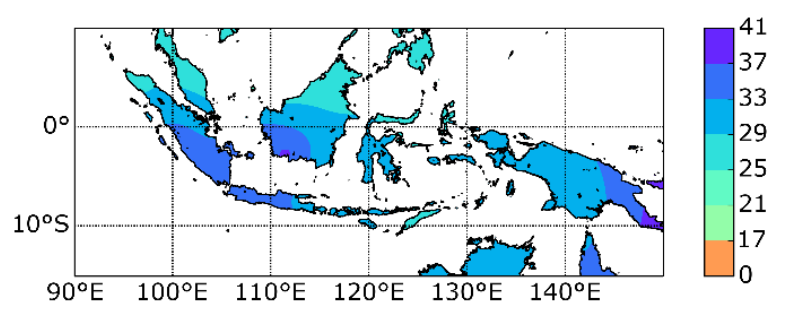

(b)

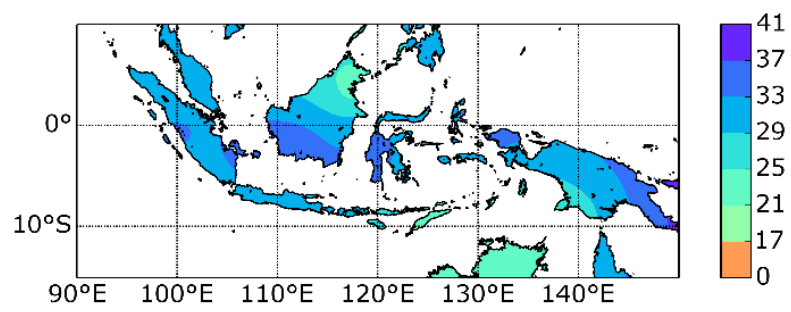

(d)

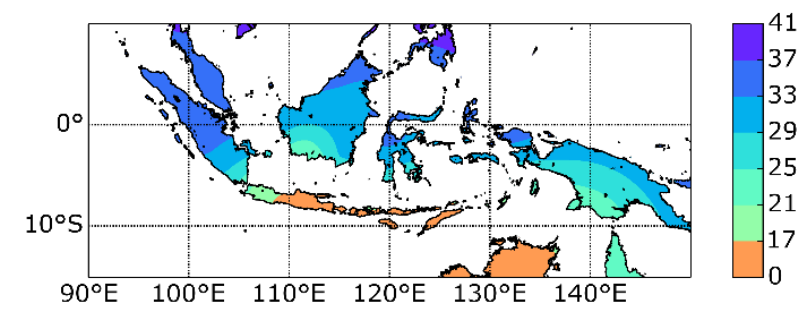

(f)

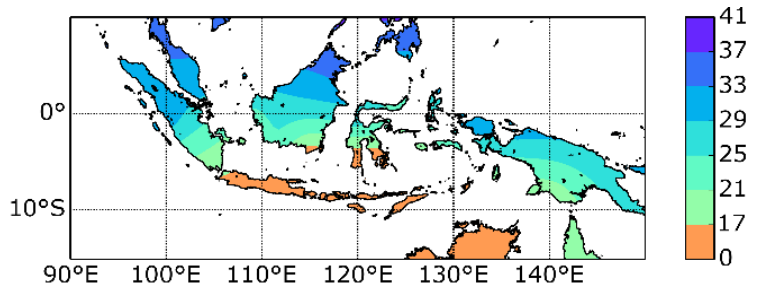

(h)

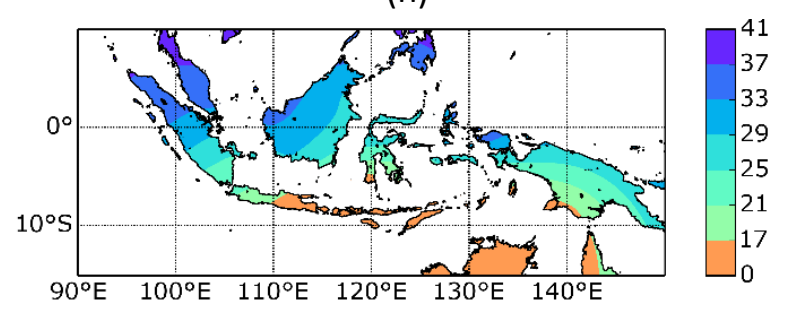

(j)

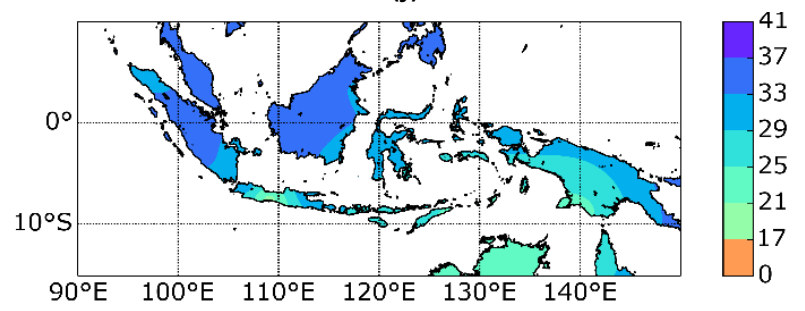

(I)

Gambar 1. Sebaran K-Index (KI) rata-rata bulanan Tahun 2019, bulan (a) Januari, (b) Februari, (c) Maret, (d) April, (e) Mei, (f) Juni, (g) Juli, (h) Agustus, (i) September, (j) Oktober, (k) November, (l) Desember. 
dan NTB cenderung lebih stabil. Pada bulan Mei (Gambar 2.e) sebagian wilayah Indonesia berada pada kategori potensi konveksi sedang yaitu Sumatera, Kalimantan, dan Sulawesi, sedangkan Jawa, Bali, NTT, NTB, dan Papua memiliki potensi konveksi lemah. Pada bulan Juni (Gambar 2.f) sebagian besar wilayah Indonesia mulai berada pada kondisi stabil, wilayah yang masih memiliki potensi konveksi lemah diantaranya Sumatera bagian utara, Kalimantan bagian utara, dan Sulawesi bagian utara.

Analisis spasial indeks Showalter pada bulan Juli (Gambar 2.g), secara keseluruhan kondisi atmosfer wilayah Indonesia dominan stabil, potensi konveksi lemah hingga sedang (nilai SI lebih dari -1 di seluruh wilayah Indonesia). Wilayah Indonesia dengan kondisi potensi konveksi paling tinggi (nilai SI: -1 hingga 1) yaitu daerah: bagian utara Sumatera, Kalimantan Utara, dan Kotawaringin, Sulawesi bagian utara, Maluku Utara, dan Sorong. Selanjutnya dengan potensi konveksi sedang (nilai SI 1 hingga 4), yaitu daerah Sumatera bagian selatan, Kalimantan Barat, Kalimantan Tengah, Kalimantan Selatan, sebagian Kalimantan Timur, Pulau Jawa, Sulawesi bagian tengah hingga selatan, Maluku, dan Papua bagian tengah. Wilayah Indonesia dengan kondisi atmosfer paling stabil (konveksi lemah) (nilai Sı lebih dari 4), yaitu Bali, Nusa Tenggara Barat, Nusa Tenggara Timur, dan Merauke.

Pada bulan Agustus (Gambar 2.h), distribusi spasial Indeks Showalter di sebagian besar wilayah Indonesia cenderung sama dengan kondisi pada bulan Juli. Wilayah Jawa Timur, Gorontalo, dan Manado nilai rata-rata bulanan SI meningkat (menjadi lebih stabil dari bulan Juli). Sedangkan wilayah Merauke nilai rata-rata bulanan SI menurun, namun masih dalam kategori stabil (nilai SI lebih dari 4), potensi konveksi lemah.

Pada bulan September (Gambar 2.i), wilayah paling labil yaitu di wilayah Aceh dan Sumatera Utara, namun masih dalam kategori potensi konveksi sedang (nilai SI 0 hingga 2). Pulau Kalimantan, Sulawesi bagian utara, Maluku Utara, dan Sorong nilai SI meningkat dari bulan Agustus (nilai SI 2 hingga 4), potensi konveksi sedang. Di wilayah Jawa Timur, Bali, Nusa Tenggara Barat, Nusa Tenggara Timur, Sulawesi Selatan dan Sulawesi Tenggara, Maluku, dan Merauke, kondisi atmosfer paling stabil (nilai SI lebih dari 4), potensi konveksi lemah.

Pada bulan Oktober (Gambar 2. j) wilayah paling labil (nilai SI -1 hingga 2) tersebar di wilayah Sumatera bagian utara, sebagian besar Pulau Kalimantan, Maluku Utara, dan Papua Barat (Sorong). Wilayah Pulau Jawa, Bali, Pulau
Sulawesi, Maluku, dan Papua memiliki potensi konveksi lemah (nilai SI 4 hingga 6). Wilayah Nusa Tenggara Timur dan Nusa Tenggara Barat merupakan wilayah paling stabil meskipun nilai SI menurun (nilai SI 6 hingga 8), dalam kategori potensi konveksi lemah.

Pada bulan November (Gambar 2.k) wilayah paling labil (nilai SI -2 hingga 2) tersebar di wilayah Pulau Sumatera bagian utara, Banten, DKI Jakarta, Jawa Barat, Jawa Tengah, sebagian besar Pulau Kalimantan kecuali Kalimantan Selatan, dan Papua Barat (Sorong). Wilayah Jawa Timur, Pulau Sulawesi, Maluku potensi konveksi sedang (nilai SI 2 hingga 4). Wilayah paling stabil (nilai SI 4 hingga 7), yaitu wilayah Nusa Tenggara Timur, Nusa Tenggara Barat, dan Merauke, meskipun nilai SI di wilayah ini menurun dari bulan Oktober.

Pada bulan Desember (Gambar 2.I) secara keseluruhan di wilayah Indonesia, nilai SI menurun dari bulan November, nilai SI dalam rentang -2 hingga 3 (dalam kategori konveksi sedang). Wilayah paling labil (nilai SI -2 hingga 1), yaitu Pulau Sumatera bagian selatan, Sebagian besar Pulau Kalimantan kecuali sebagian wilayah Kalimantan Selatan, Banten, DKI Jakarta, Jawa Timur, Bali, Sulawesi tengah, dan Sorong.

Nilai SI yang menunjukkan potensi konveksi sedang di seluruh wilayah Indonesia terjadi pada bulan Desember dan Januari sesuai dengan terjadinya monsun Asia. Sedangkan kondisi paling stabil berdasarkan nilai SI di Indonesia terjadi pada bulan September dimana pada bulan ini merupakan akhir monsun Australia. Nilai SI ratarata tahunan di Indonesia menurut Syaifullah (2017) berkisar antara 1 hingga 2.

Kondisi labilitas udara di Indonesia berdasarkan Lifted Index (LI) ditunjukkan pada Gambar 3. Pada bulan Januari (Gambar 3. a) sebagian besar wilayah Indonesia memiliki potensi konveksi lemah dengan nilai LI antara -2 hingga 0 , sedangkan wilayah yang memiliki potensi konveksi sedang yaitu sebagian besar Kalimantan dan Jawa Tengah dengan nilai LI -4 hingga -2. Pada bulan Februari (Gambar 3. b) wilayah yang memiliki potensi konveksi sedang diantaranya Sumatera, Jawa, Bali, Nusa Tenggara dan barat daya Kalimantan. Wilayah lainnya memiliki potensi konveksi lemah. Pada bulan Maret (Gambar 3.c) sebagian besar wilayah Indonesia masih memiliki potensi konveksi lemah dengan nilai LI antara -2 hingga 2 , sedangkan wilayah yang memiliki potensi konveksi sedang dengan nilai LI -4 hingga -2 adalah sebagian besar Sumatera. Kondisi labilitas pada bulan April (Gambar 3.d) cenderung sama dengan bulan Maret yaitu masih terdapat wilayah dengan potensi konveksi 


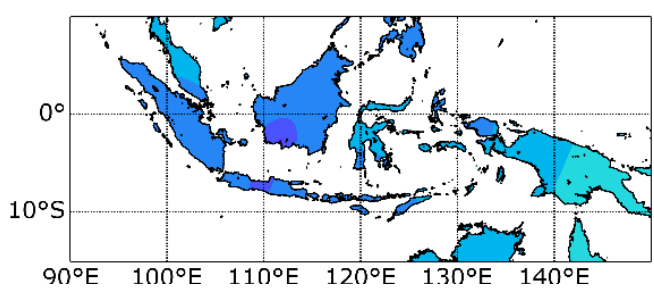

(a)

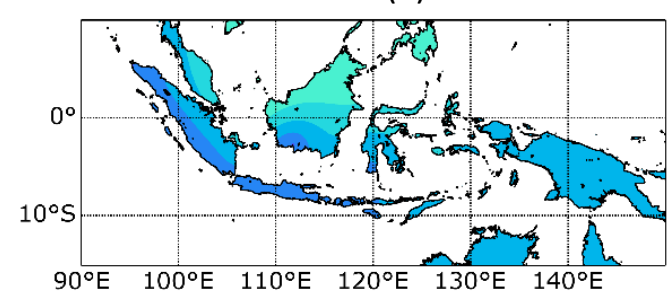

(c)

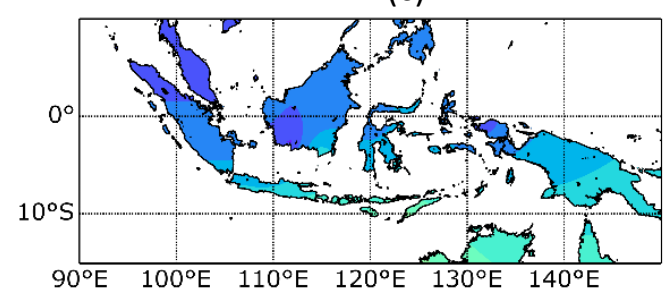

(e)

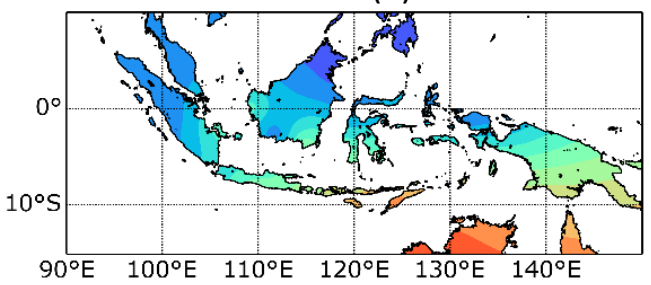

(g)

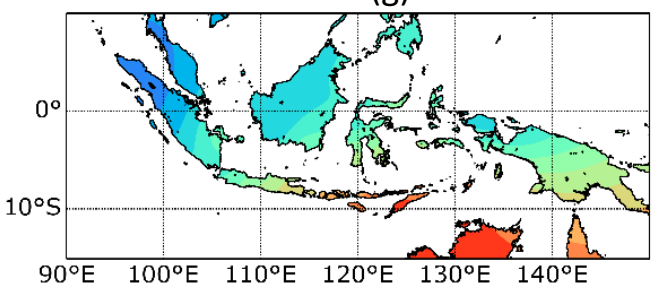

(i)

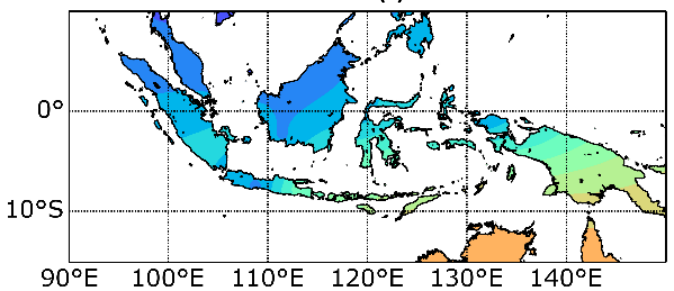

(k)

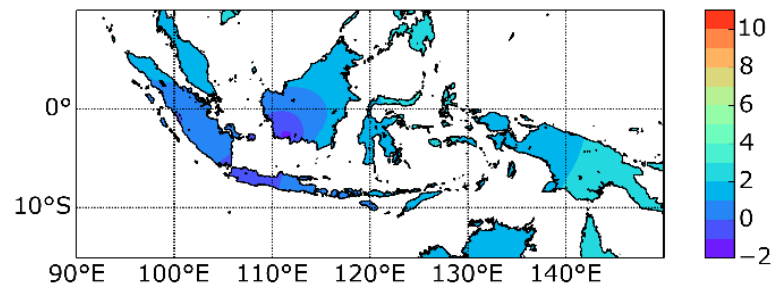

(b)

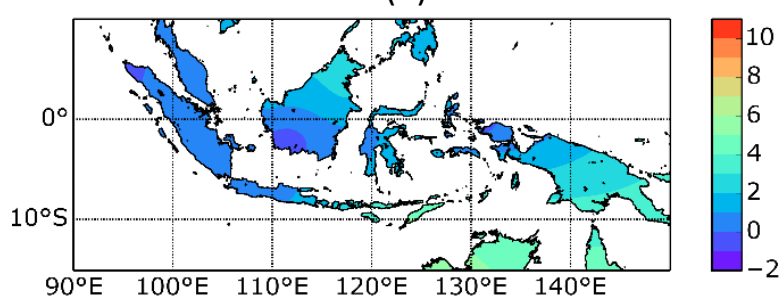

(d)

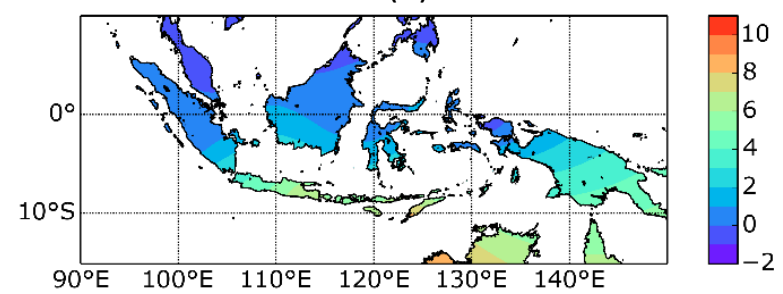

(f)

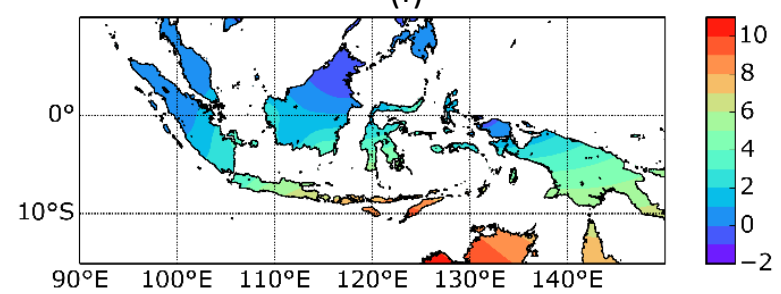

(h)

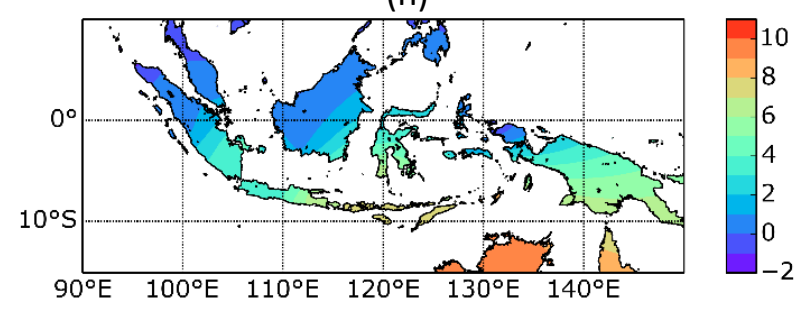

(j)

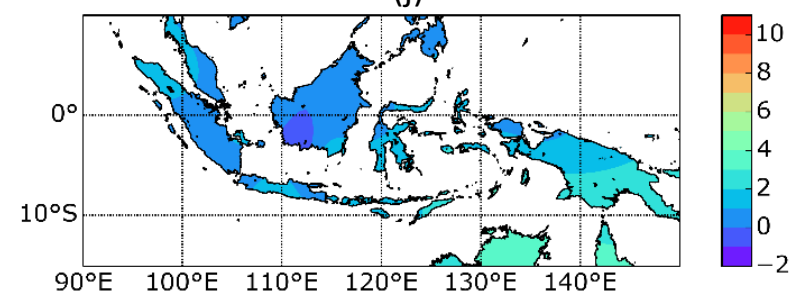

(l)

Gambar 2. Sebaran Showalter Index (SI) rata-rata bulanan Tahun 2019, bulan (a) Januari, (b) Februari, (c) Maret, (d) April, (e) Mei, (f) Juni, (g) Juli, (h) Agustus, (i) September, (j) Oktober, (k) November, dan (I) 
lemah dan sedang. Pada bulan Mei (Gambar 3. e) sebagian besar wilayah Indonesia memiliki potensi konveksi lemah dengan nilai LI antara -2 hingga 2 , sedangkan wilayah yang memiliki potensi konveksi sedang dengan nilai LI -6 hingga -2 adalah sebagian Sumatera dan sebagian besar Kalimantan. Pada bulan Juni (Gambar 3. f) sebagian besar wilayah Indonesia memiliki potensi konveksi lemah dengan nilai LI antara -2 hingga 4, sedangkan wilayah yang memiliki potensi konveksi sedang dengan nilai LI -4 hingga -2 adalah sebagian besar Sumatera.

Analisis spasial Lifted Index (LI) pada bulan Juli (Gambar 3.g), wilayah Indonesia dengan kondisi paling labil, potensi konveksi sedang (nilai LI -4 hingga -2), yaitu daerah bagian utara, Kalimantan Utara, dan Kalimantan Tengah. Wilayah dengan kondisi potensi konveksi lemah (nilai LI lebih dari -2), yaitu daerah sebagian Aceh, Sumatera Selatan, Lampung, Kalimantan Barat, Kalimantan Selatan, dan sebagian Kalimantan Timur, Pulau Jawa, Bali, Nusa Tenggara Barat, Nusa Tenggara Timur, Sulawesi, Maluku, dan Pulau Papua.

Pada bulan Agustus (Gambar 3.h), wilayah Indonesia dengan potensi konveksi sedang (nilai LI -6 hingga -2), yaitu daerah bagian utara Pulau Sumatera, Kalimantan Utara, dan sebagian Papua Barat. Selain wilayah tersebut, memiliki kondisi potensi konveksi lemah (nilai LI lebih dari -2). Kondisi atmosfer paling stabil di Indonesia pada bulan ini yaitu di wilayah Bali, Nusa Tenggara Barat, dan Nusa Tenggara Timur (nilai LI lebih dari 4).

Pada bulan September (Gambar 3.i), kondisi atmosfer di wilayah Indonesia sebagian besar memiliki potensi konveksi lemah (nilai LI lebih dari -2), kecuali di wilayah Aceh, Sumatera Utara, Sumatera Barat, Riau, dan Kalimantan Barat dalam kategori potensi konveksi sedang (nilai LI -4 hingga -2). Kondisi atmosfer paling stabil di Indonesia pada bulan September masih di wilayah Bali, Nusa Tenggara Barat, dan Nusa Tenggara Timur dan meluas ke wilayah Sulawesi Selatan, Sulawesi Tenggara, dan sebagian Merauke (nilai LI lebih dari 4).

Pada bulan Oktober (Gambar 3. j), kondisi atmosfer di wilayah Indonesia sebagian besar masih memiliki potensi konveksi lemah (nilai LI lebih dari -2), kecuali di wilayah sebagian Kalimantan Barat, Kalimantan Tengah, dan sebagian Papua Barat, dalam kategori potensi konveksi sedang (nilai LI -4 hingga -2). Kondisi atmosfer di wilayah Bali, Nusa Tenggara Barat, Nusa Tenggara Timur, Sulawesi Selatan, Sulawesi Tenggara, dan sebagian Merauke nilai LI menurun dari bulan September (nilai LI 2 hingga 4), masih dalam kategori potensi konveksi lemah.
Pada bulan November (Gambar 3.k) wilayah paling labil (nilai LI -4 hingga -2) tersebar di wilayah Kalimantan Barat, Kalimantan Tengah, Kalimantan Utara, dan Papua Barat (Sorong), dalam kategori potensi konveksi sedang. Selain wilayah tersebut memiliki potensi konveksi lemah (nilai LI lebih dari -2).

Pada bulan Desember (Gambar 3.I) wilayah dengan kategori potensi konveksi sedang (nilai LI -4 hingga -2) tersebar di wilayah Sumatera Barat, Riau, Bengkulu, Jambi, Kalimantan Tengah, Kalimantan Utara, Nusa Tenggara Barat, Nusa Tenggara Timur, Maluku Utara, dan Papua Barat. Selain wilayah tersebut nilai LI dalam rentang -2 hingga 0 (dalam kategori konveksi lemah). Berdasarkan lifted index, potensi konveksi lemah dan sedang terjadi di seluruh wilayah Indonesia dari bulan Januari hingga Desember. Menurut Chakraborty et al. (2018) nilai LI yang paling labil terjadi pada pre-monsun dengan nilai -8 hingga -4 . Kondisi paling stabil menurut Chakraborty et al. (2018) terjadi pada musim dingin, sedangkan di Indonesia kondisi paling stabil terjadi pada bulan September.

Kondisi Total-totals Index (TT) Indonesia pada tahun 2019 ditampilkan pada Gambar 4. Kondisi TT pada bulan Januari (Gambar 4.a) menunjukkan sebagian besar wilayah Indonesia memiliki potensi konveksi sedang kecuali Papua Barat dan Sulawesi Bagian Utara potensi konveksi labil lemah. Kondisi bulan Februari (Gambar 4.b) relatif sama dengan kondisi bulan Januari dengan penambahan wilayah kategori potensi konveksi lemah di Kalimantan Timur. Pada bulan Maret (Gambar 4.c) wilayah yang memiliki potensi konveksi sedang diantaranya Sumatera, Jawa, Bali, NTT, NTB, dan Papua. Sedangkan wilayah yang memiliki potensi konveksi lemah adalah Kalimantan, Sulawesi, dan Papua Barat.

Pada bulan April (Gambar 4.d) wilayah yang memiliki potensi konveksi sedang diantaranya Sumatera, sebagian Kalimantan, Jawa, Sulawesi, Bali, NTB, dan Papua, sedangkan wilayah yang memiliki potensi konveksi lemah diantaranya Kalimantan bagian Utara, NTT, dan Papua Barat. Pada bulan Mei (Gambar 4.e) wilayah yang berpotensi konveksi sedang diantaranya Sumatera, Kalimantan, Sulawesi, dan Papua. Sedangkan yang berpotensi konveksi lemah diantaranya adalah Jawa, Bali, NTT, NTB, dan Papua Barat. Pada bulan Juni (Gambar 4.f) wilayah yang berpotensi konveksi sedang diantaranya Sebagin besar Sumatera, sebagian Sulawesi, dan Papua. Sedangkan wilayah lainnya berpotensi konveksi lemah dengan daerah paling stabil adalah NTT. 


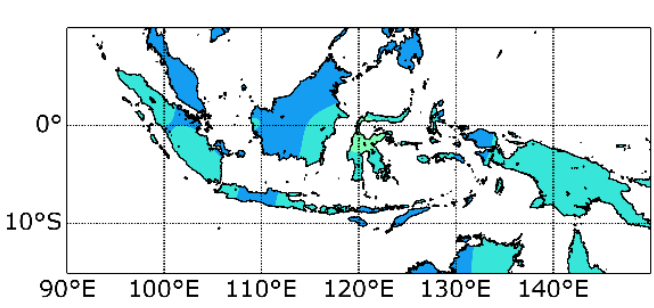

(a)

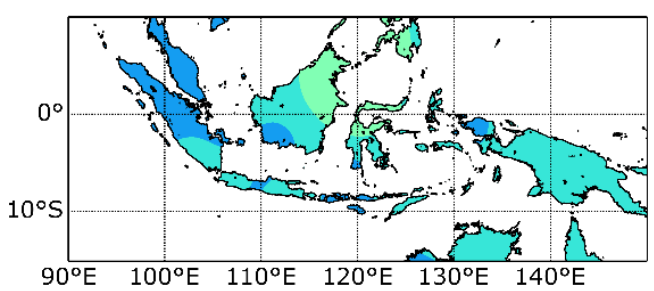

(c)

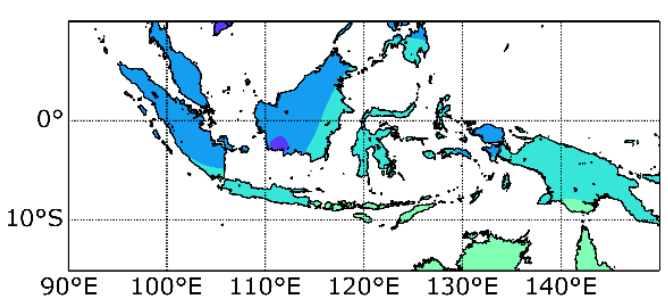

(e)

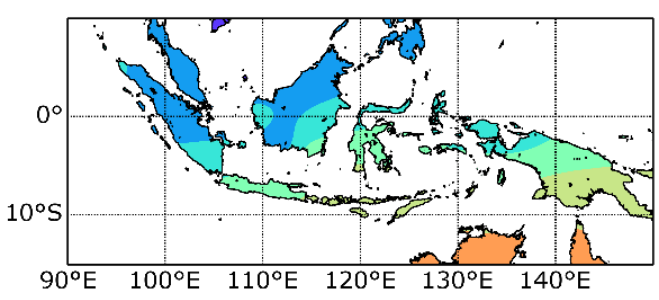

(g)

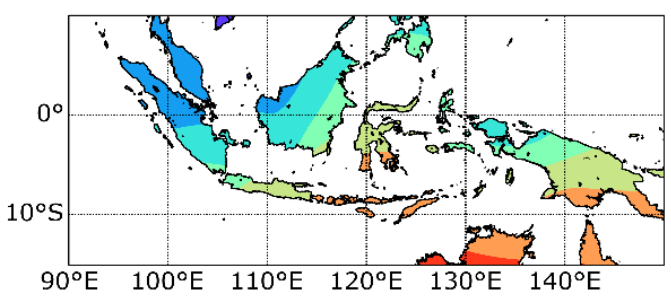

(i)

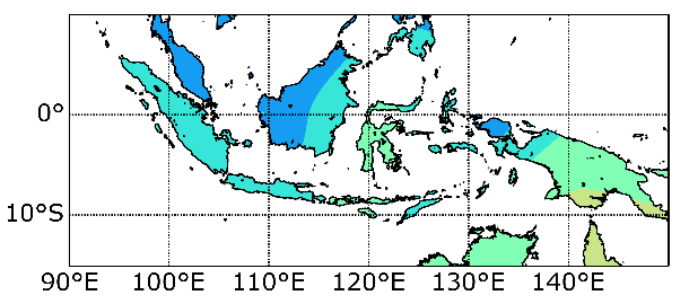

(k)

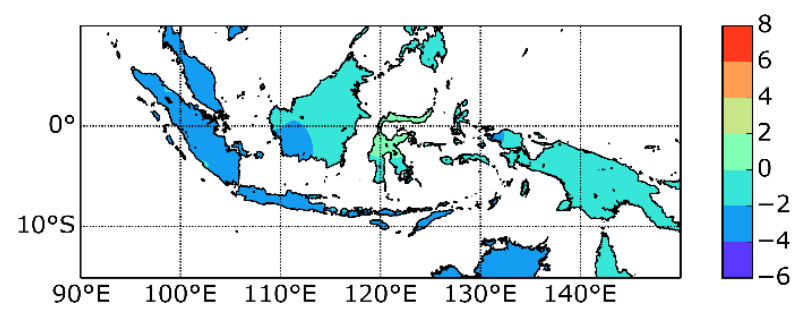

(b)

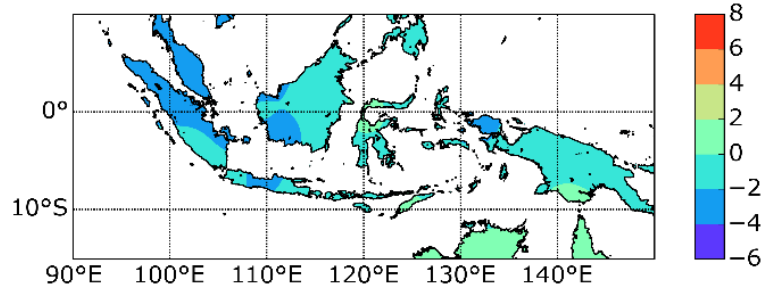

(d)

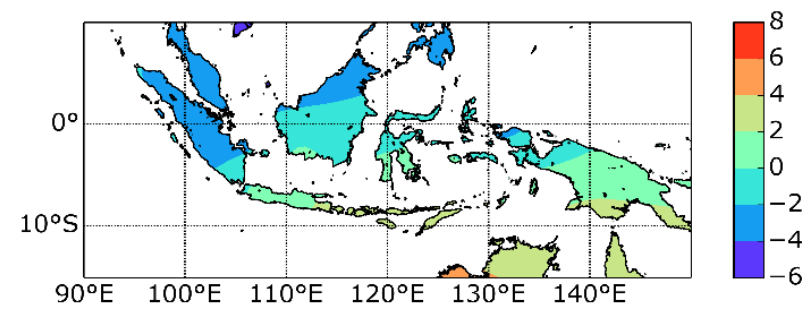

(f)

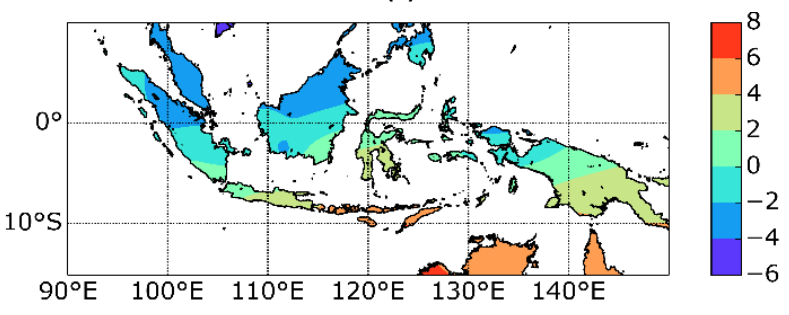

(h)

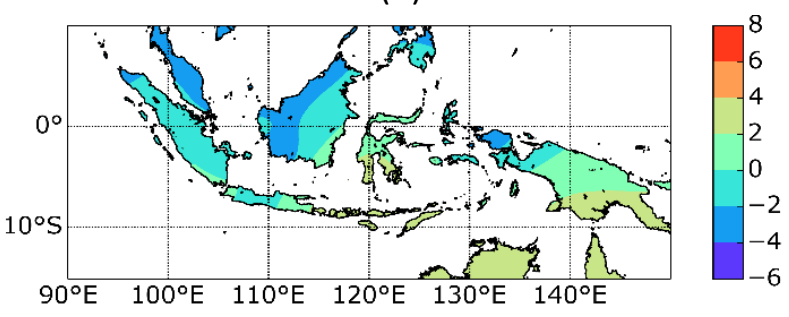

(j)

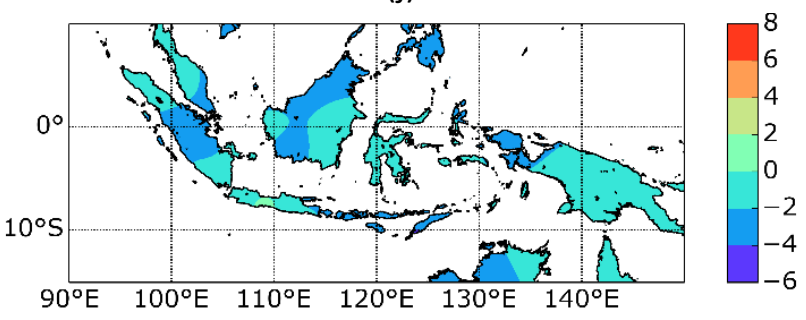

(I)

Gambar 3. Sebaran Lifted Index (LI) rata-rata bulanan Tahun 2019, bulan (a) Januari, (b) Februari, (c) Maret, (d) April, (e) Mei, (f) Juni, (g) Juli, (h) Agustus, (i) September, (j) Oktober, (k) November, dan (I) 
Analisis spasial Total-totals Index (TT) pada bulan Juli (Gambar 4. g), potensi konveksi sedang (nilai KI 42 hingga 46), yaitu daerah sebagian besar Pulau Sumatera, sebagian besar Pulau Kalimantan, Sulawesi Tengah, Gorontalo, Sulawesi Utara, Maluku Utara, dan pesisir utara Pulau Papua. Selain wilayah tersebut, kondisi atmosfer memiliki potensi konveksi lemah (nilai TT kurang dari 42). Kondisi paling stabil (nilai TT kurang dari 34), yaitu wilayah Nusa Tenggara Timur.

Pada bulan Agustus (Gambar 4.h), distribusi spasial TT cenderung sama dengan bulan Juli, kecuali wilayah Kalimantan Barat nilai TT meningkat (nilai TT 42 hingga 46) dalam kategori potensi konveksi sedang. Kondisi paling stabil (nilai TT kurang dari 34) juga masih terlihat di wilayah Nusa Tenggara Timur.

Pada bulan September (Gambar 4.i), wilayah Indonesia dengan potensi konveksi sedang (nilai TT 42 hingga 46) hanya di wilayah bagian utara Pulau Sumatera, selain wilayah tersebut, memiliki kondisi potensi konveksi lemah (nilai TT kurang dari 42). Kondisi atmosfer paling stabil (nilai TT kurang dari 34) pada bulan ini meluas, yaitu di wilayah sebagian Nusa Tenggara Barat, dan Nusa Tenggara Timur.

Pada bulan Oktober (Gambar 4. j), kondisi atmosfer di wilayah bagian utara Sumatera, Kalimantan Barat, Kalimantan Tengah, Kalimantan Utara, dan sebagian Sorong memiliki potensi konveksi sedang (nilai TT 42 hingga 46). Selain wilayah tersebut, memiliki kondisi potensi konveksi lemah (nilai TT kurang dari 42). Wilayah Nusa Tenggara Barat dan Nusa Tenggara Timur pada bulan sebelumnya merupakan wilayah paling stabil (nilai TT kurang dari 34), pada bulan Oktober nilai TT meningkat (TT 34 hingga 38), meskipun masih dalam kategori potensi konveksi lemah.

Pada bulan November (Gambar 4.k) wilayah paling labil, potensi konveksi sedang (nilai TT 42 hingga 46) hampir sama dengan bulan Oktober, dan meluas ke wilayah Banten, DKI, dan Jawa Barat. Selain wilayah tersebut, memiliki kondisi potensi konveksi lemah (nilai TT kurang dari 42) dengan sebaran wilayah cenderung sama dengan bulan Oktober.

Pada bulan Desember (Gambar 4.I) wilayah dengan kategori potensi konveksi sedang (nilai KI 42 hingga 46) meluas dari bulan November, yaitu di wilayah Pulau Sumatera (kecuali Aceh), Pulau Kalimantan, Banten, sebagian Jawa Timur, Pulau Sulawesi (kecuali Sulawesi Utara), Maluku Utara, dan Papua bagian utara. Selain wilayah tersebut nilai TT dalam rentang 38 hingga 42 (dalam kategori konveksi lemah), yaitu di wilayah Aceh, Jawa Barat, Jawa Tengah, sebagian Jawa Timur, Sulawesi Utara, Maluku, dan Papua bagian selatan. Berdasarkan Total-totals Index (TT), potensi konveksi lemah dan sedang terjadi di seluruh wilayah Indonesia dari bulan Januari hingga Desember. Sedangkan kondisi paling stabil terjadi pada bulan September. Chakraborty et al. (2018) menjelaskan bahwa TT yang menunjukkan kondisi paling labil terjadi pada pre-monsoon dengan range 45-50, namun berdasarkan kajian yang dilakukan selama tahun 2019 di Indonesia nilai TT tidak ada yang lebih dari 46.

Kondisi curah hujan $(\mathrm{CH})$ bulanan Indonesia pada tahun 2019 ditampilkan pada Gambar 5. Curah hujan tinggi terjadi pada bulan Desember (Gambar 5.I), Januari (Gambar 5.a), Februari (Gambar 5.b), dan Maret (Gambar 5.c) dengan kisaran 300 hingga $440 \mathrm{~mm} / \mathrm{bulan}$. Hal ini sesuai dengan kondisi indeks stabilitas udara yang menunjukkan pada bulan-bulan tersebut sebagian besar memiliki potensi konveksi sedang. Pada bulan April kondisi indeks stabilitas udara melemah di wilayah Bali, NTB, dan NTT diikuti dengan penurunan curah hujan pada wilayah tersebut (Gambar 5.d). Pada bulan Mei (Gambar 5.e) sebagian besar Pulau Jawa, Bali, NTB, dan NTT memiliki curah hujan kurang dari $40 \mathrm{~mm} /$ bulan sedangkan untuk wilayah lainnya curah hujan bulanan masih mencapai 120 hingga $400 \mathrm{~mm} /$ bulan. Pada bulan Juni (Gambar 5.f) kondisi curah hujan cenderung sama dengan bulan Mei dengan sedikit penambahan wilayah yang memiliki curah hujan rendah di Sumatera bagian selatan.

Pada bulan Juli (Gambar 5.g) wilayah dengan curah hujan kurang dari $40 \mathrm{~mm} /$ bulan semakin meluas hingga Sumatera bagian selatan, Kalimantan bagian selatan, dan Sulawesi bagian selatan dan diikuti dengan penurunan curah hujan di wilayah lainnya berkisar antara 120 hingga $360 \mathrm{~mm} /$ bulan. Pada bulan Agustus (Gambar 5.h) kondisi curah hujan hampir sama dengan bulan Juli dengan sedikit penambahan luas wilayah yang memiliki curah hujan kurang dari $40 \mathrm{~mm} / \mathrm{bulan}$ dan penurunan curah hujan pada wilayah lainnya menjadi 120 hingga $280 \mathrm{~mm} /$ bulan. 


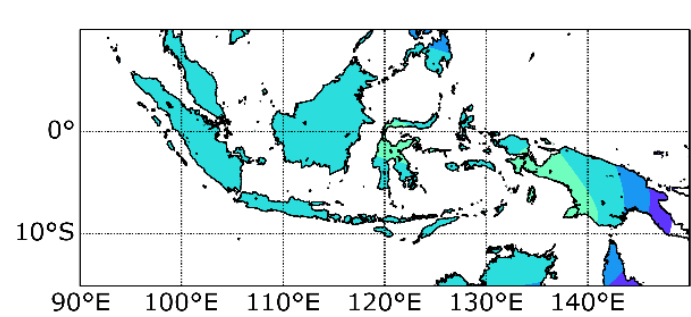

(a)

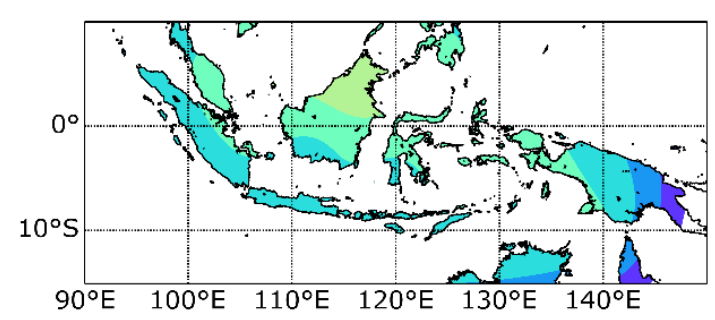

(c)

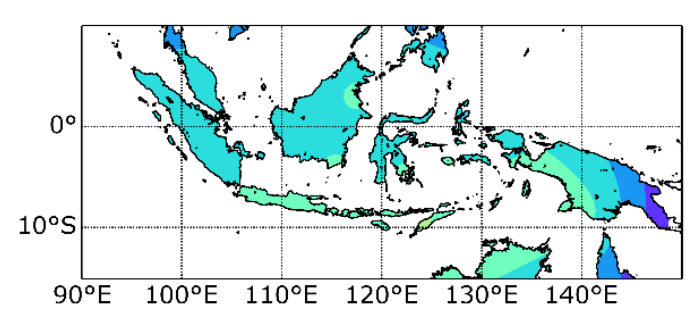

(e)

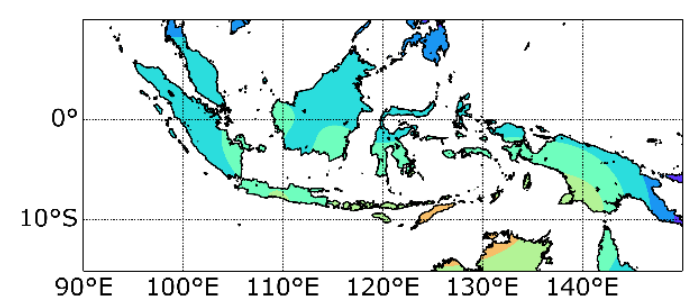

(g)

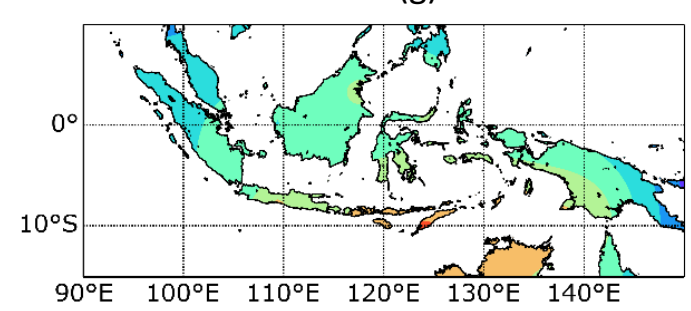

(i)

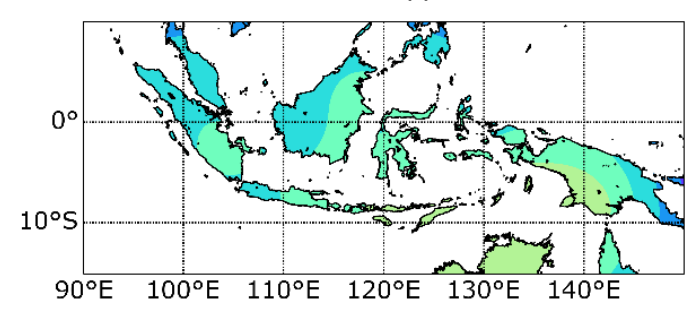

(k)
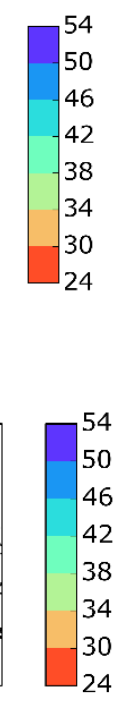

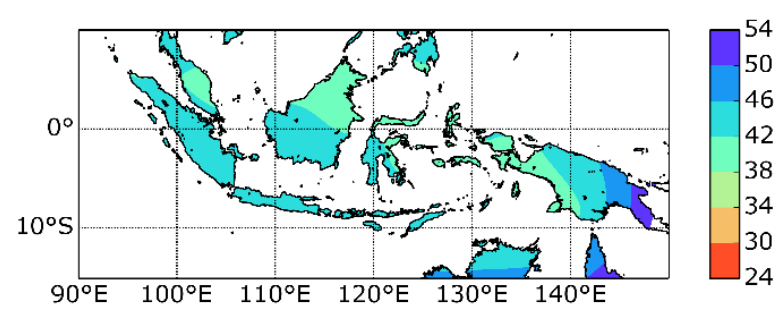

(b)

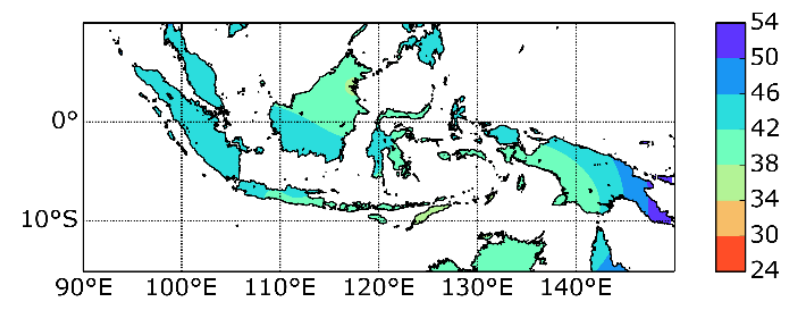

(d)

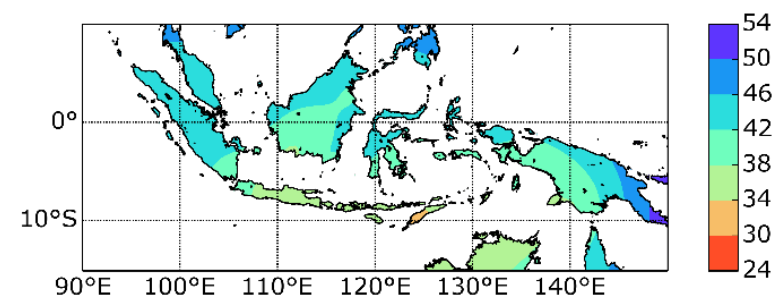

(f)

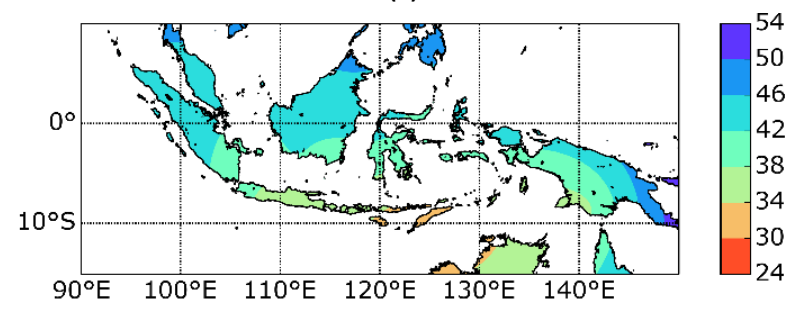

(h)

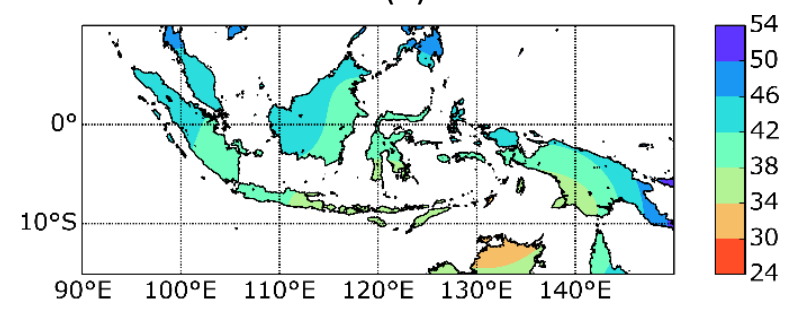

(j)

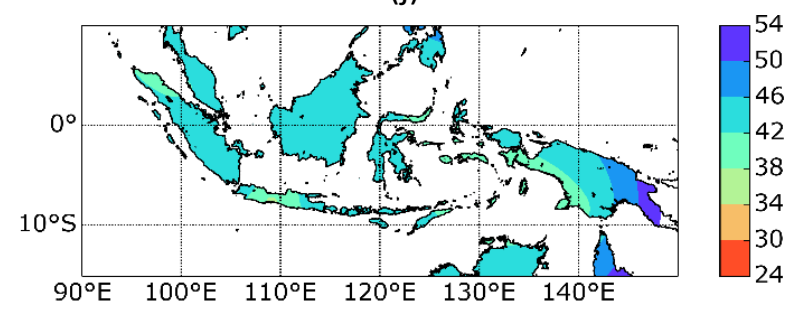

(I)

Gambar 4. Sebaran Total-Total Index (TT) rata-rata bulanan Tahun 2019, bulan (a) Januari, (b) Februari, (c) Maret, (d) April, (e) Mei, (f) Juni, (g) Juli, (h) Agustus, (i) September, (j) Oktober, (k) November, dan (l) 


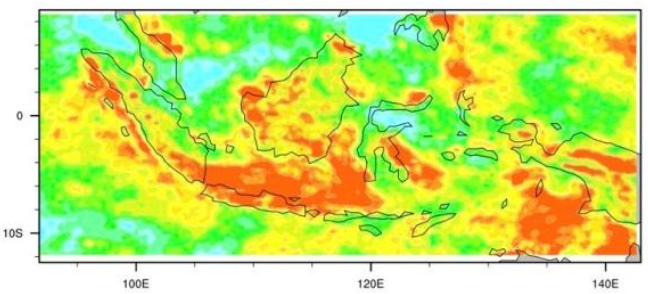

(a)

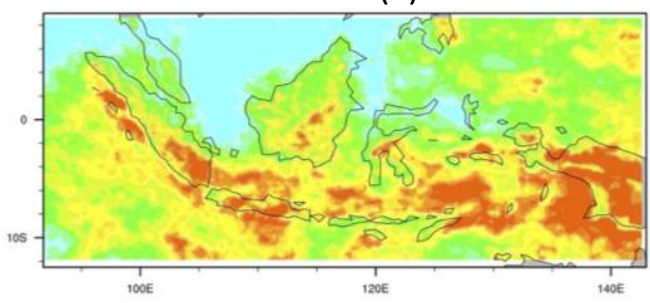

(c)

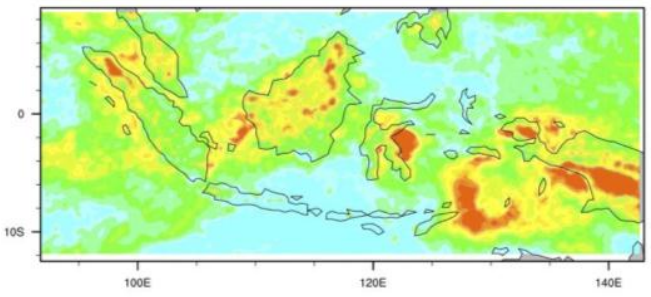

(e)

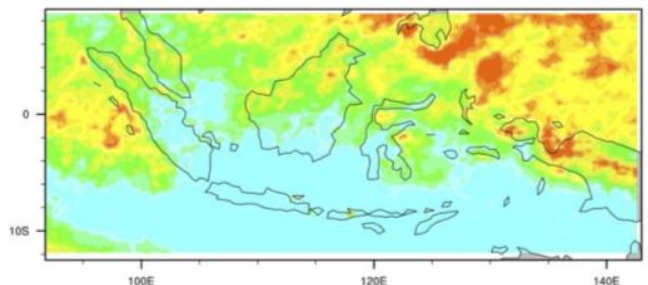

(g)

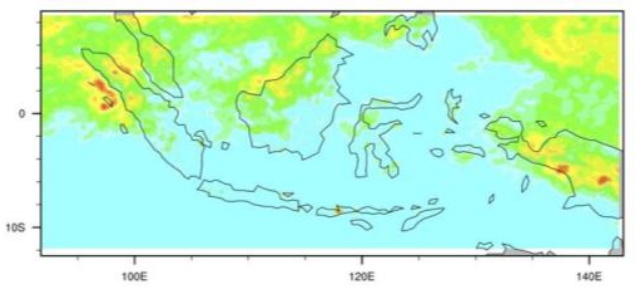

(i)

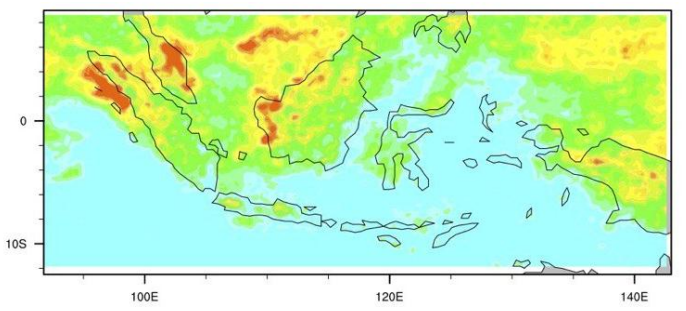

(k)
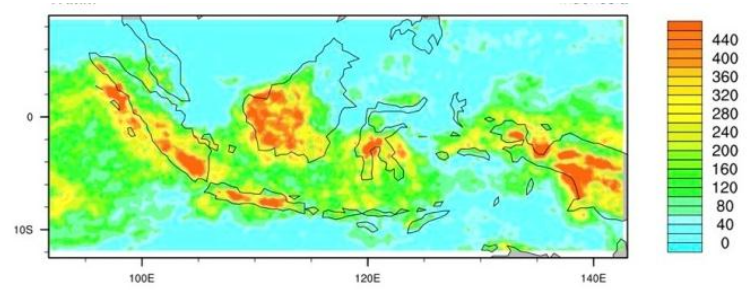

(b)

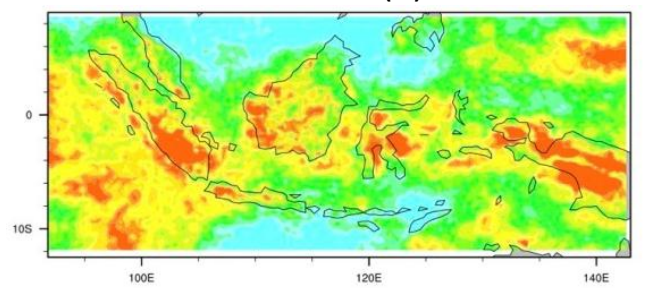

$\begin{array}{ll} & 440 \\ & 400 \\ & 400 \\ & 360 \\ & 320 \\ & 280 \\ & 240 \\ & 200 \\ & 160 \\ & 120 \\ & 80 \\ & 40 \\ & 40 \\ & 0\end{array}$

(d)
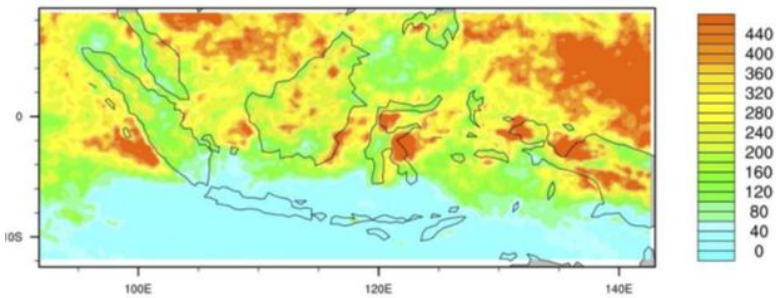

(f)
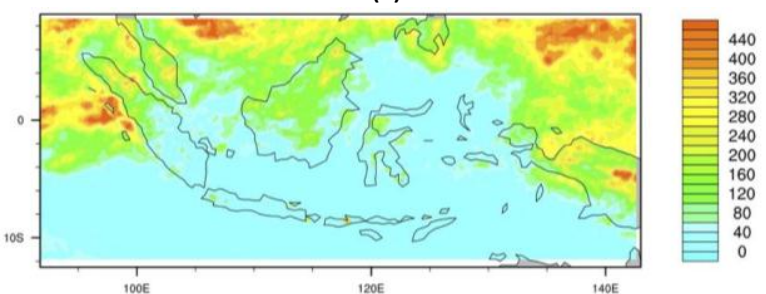

(h)
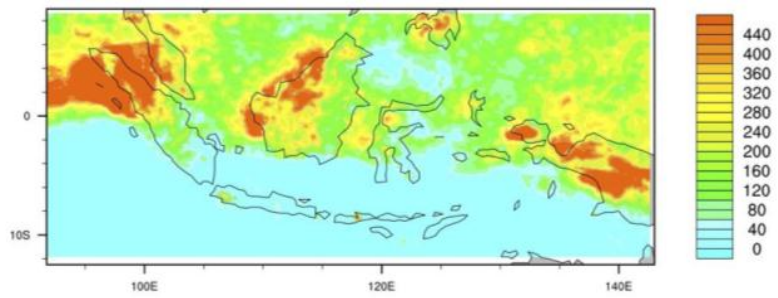

(j)
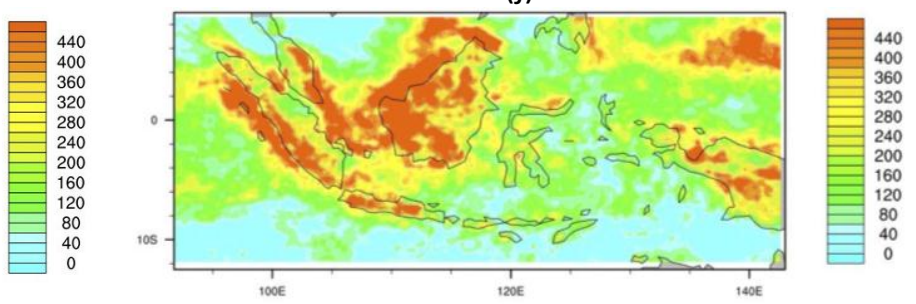

(I)

Gambar 5. Curah hujan bulanan Indonesia (TRMM) Tahun 2019 bulan (a) Januari, (b) Februari, (c) Maret, (d) April, (e) Mei, (f) Juni, (g) Juli, (h) Agustus, (i) September, (j) Oktober, (k) November, dan (I) Desember 
Pada bulan September (Gambar 5.i) merupakan bulan paling kering dengan sebagian besar wilayah Indonesia memiliki curah hujan kurang dari $40 \mathrm{~mm} /$ bulan, sedangkan wilayah dengan $\mathrm{CH}$ lebih dari $40 \mathrm{~mm} /$ bulan hanya di Sumatera bagian utara, Kalimantan bagian utara, dan Papua. Kondisi indeks stabilitas atmosfer pada bulan September merupakan kondisi paling stabil, hal ini sangat berpengaruh terhadap jumlah curah hujan bulanan pada bulan ini. Pada bulan Oktober (Gambar 5. j) mulai terjadi peningkatan curah hujan di wilayah Indonesia bagian utara mulai dari Sumatera bagian utara, sebagian besar Kalimantan, Sebagian Sulawesi, dan Papua berkisar antara 120 hingga 440 $\mathrm{mm} /$ bulan. Pada bulan November (Gambar 5.k) terjadi peningkatan sebaran curah hujan, curah hujan lebih dari $40 \mathrm{~mm} /$ bulan terjadi di sebagian besar wilayah Indonesia, hanya beberapa wilayah yang curah hujan kurang dari 40 $\mathrm{mm} /$ bulan diantaranya Bali dan NTB.

\section{KESIMPULAN}

Kondisi stabilitas atmosfer melemah atau menguat sangat berpengaruh terhadap sebaran curah hujan di Indonesia secara spasial. Bulan Januari merupakan bulan dengan nilai $\mathrm{KI}, \mathrm{SI}, \mathrm{LI}$, dan TT paling kuat diikuti dengan sebaran curah hujan bulanan yang tinggi. Kondisi ini disebabkan karena pada bulan Januari terjadi monsoon Asia di Indonesia. Sedangkan bulan September merupakan bulan paling stabil dengan nilai $\mathrm{KI}, \mathrm{SI}$, $\mathrm{LI}$, dan TT paling lemah diikuti dengan kondisi kering di Indonesia. Hal ini disebabkan karena pada bulan September, wilayah Indonesia memasuki akhir dari monsun Australia. Pergerakan pelemahan indeks stabilitas udara dimulai dari wilayah NTT, NTB, Bali hingga terus melebar ke arah utara dimulai pada bulan Juni, dan perlahan menguat pada bulan Oktober.

\section{DAFTAR PUSTAKA}

Athoillah, I., Dewi, S., \& Renggono, F. (2016). Perbandingan Pengukuran Radiometer dan Radiosonde pada Musim Hujan di Dramaga Bogor. Jurnal Sains \& Teknologi Modifikasi Cuaca, 17(2), 75-82. doi: 10.29122/jstmc.v17i2.640

Budiarti, M., Muslim, M., \& Ilhamsyah, Y. (2012). Studil Indeks Stabilitas Udara Terhadap Prediksi Kejadian Badai Guntur (Thunderstorm) Di Wilayah Stasiun Meteorologi Cengkareng Banten. Jurnal Meteorologi dan Geofisika, 13, 110-117. doi: 10.31172/jmg.v13i2.125

Chakraborty, R., Basha, G., \& Venkat Ratnam, M. (2018). Diurnal and long-term variation of instability indices over a tropical region in
India. Atmospheric Research, 207(2017), 145-154. doi: 10.1016/j.atmosres.2018.03.012

Dodo, G. (2007). Perbandingan Curah Hujan Bulanan dari Data Pengamatan Permukaan, Satelit TRMM dan Model Permukaan NOAA. Jurnal Meteorologi dan Geofisika, Vol. 9 No.(Juli), 1-10. doi: 10.31172/jmg.v9i1.17

Ferdiansyah, A. (2012). Potensi Parameter Keluaran Raob (Rawinsonde Observation Programs) sebagai Indikator Kunci dalam Analisis Curah Hujan. Skripsi. Tidak Diterbitkan. Institut Pertanian Bogor. Bogor.

Fibriantika, E., \& Alhaqq, R. I. (2018). Profil Vertikal Atmosfer Selama Aktifitas Siklon Tropis Cempaka dan Dahlia. Meteorologi dan Geofisika, 19(2), 49-58. doi: 10.31172/jmg.v19i2.589

Moron, V., Robertson, A. W., \& Boer, R. (2009). Spatial Coherence and Seasonal Predictability of Monsoon Onset over Indonesia. Journal of Climate, 22(3), 840850. doi: $10.1175 / 2008 J C L I 2435.1$

Nurrohman, Faqih, \& Tjasyono, B. (2016). Kajian Indeks Stabilitas Atmosfer Terhadap Kejadian Hujan Lebat di Wilayah Makassar (Studi Kasus Bulan Desember 2013 2014). Jurnal Meteorologi Klimatologi dan Geofisika, 3(2), 18-24. doi: 10.20961/prosidingsnfa.v3i0.28538

Qian, J. H., Robertson, A. W., \& Moron, V. (2010). Interactions among ENSO, the Monsoon, and Diurnal Cycle in Rainfall Variability over Java, Indonesia. Journal of the Atmospheric Sciences, 67(11), 35093524. doi: 10.1175/2010JAS3348.1

Syaifullah, M. D. (2011). Potensi Atmosfer dalam Pembentukan Awan Konvektif Pada Pelaksanaan Teknologi Modifikasi Cuaca di DAS Kotopanjang dan DAS Singkarak 2010. Jurnal Sains \& Teknologi Modifikasi Cuaca, 12(1), $9 . \quad$ doi: 10.29122/jstmc.v12i1.2185

Syaifullah, M. D. (2013). Analisis Kondisi Udara Atas Wilayah Jakarta Bulan JanuariFebruari 2013. Jurnal Sains \& Teknologi Modifikasi Cuaca, 14, No. 1, 19-27. doi: 10.29122/jstmc.v14i1.2678

Syaifullah, M. D. (2017). Analisis Kondisi Udara Atas Wilayah Indonesia dengan Data Radiosonde. Jurnal Meteorologi dan Geofisika, 18(1). doi: 10.31172/jmg.v18i1.268

Zahroh, N.F., Wayan Srimani Puspa Dewi, N., \& Harsanti, D. (2017). Indeks Labilitas Udara untuk Memprediksi Kejadian Badai Guntur pada Puncak Musim Hujan Tahun 2016. Jurnal Sains \& Teknologi Modifikasi Cuaca, 18(1), 9-15. doi: 10.29122/jstmc.v18i1.1764 